\title{
HUBUNGAN PANJANG TUNGKAI DAN BERAT BADAN TERHADAP KECEPATAN LARI SPRINT 60 METER
}

\author{
K. Mustakim, Priyanto \\ gitarasya7@gmail.com \\ Program Studi Pendidikan Kepelatihan, Olahraga Fakultas Ilmu Keolahragaan \\ Universitas Negeri Semarang
}

\begin{abstract}
ABSTRAK
Tungkai pada tiap individu mempunyai ukuran yang berbeda beda sehingga berpengaruh terhadap perbedaan kecepatan lari tiap individu. Semakin panjang tungkai seseorang memungkinkan seseorang dapat melangkah secara lebih panjang dan lebih efisien dalam menempuh jarak yang diperlombakan. Berat badan sangat berpengaruh terhadap aktivitas gerak seseorang, sebab apabila bobot tubuh berlebih atau kegemukan akan memberatkan gerak yang terjadi. Kemampuan lari 60 meter membutuhkan kecepatan secara maksimal untuk mencapai finish. Berat badan seseorang akan sangat mempengaruhi kemampuan berlari secara maksimal, karena semakin berat beban yang dibawa seorang pelari tentu akan menghambat laju kecepatan larinya.

Data yang diperoleh dianalisis untuk uji hipotesis yaitu uji korelasi sederhana, uji korelasi ganda. Hasil analisis data akhir diperoleh kesimpulan bahwa: (1)Ada hubungan panjang tungkai dengan kecepatan lari sprint 60 meter menghasilkan koefisien korelasi sebesar 0,516. (2) Ada hubungan berat badan dengan kecepatan lari sprint 60 meter menghasilkan koefisien korelasi sebesar 0,716. (3) Ada hubungan yang signifikan antara panjang tungkai, berat badan, dengan kecepatan lari sprint 60 meter menghasilkan koeffisien korelasi sebesar 0,719.
\end{abstract}

Kata Kunci : Panjang tungkai, Beratbadan, Sprint 60 meter

\section{PENDAHULUAN}

$$
\begin{aligned}
& \text { Mata pelajaran pendidikan } \\
& \text { jasmani, olahraga dan kesehatan } \\
& \text { merupakan media untuk mendorong } \\
& \text { perkembangan ketrampilan motoric, } \\
& \text { kemampuan fisik, pengetahuan, } \\
& \text { penalaran, penghayatan nilai (sikap- } \\
& \text { mental-emosional-spiritual-sosial), dan }
\end{aligned}
$$

pembiasan pola hidup sehat untuk merangsang pertumbuhan serta perkembangan yang seimbang.

$$
\text { Dengan pendidikan jasmani, }
$$
olahraga dan kesehatan, siswa akan memperoleh berbagai ungkapan yang erat kaitanya dengan kesan pribadi yang menyenangkan serta berbagai ungkapan 
yang kreatif, inovatif, terampil, memilikikebugaran jasmani, kebiasaan hidup sehat, dan memiliki pengetahuan serta pemahaman terhadap gerak manusia.

Pada umumya siswa tingkat Sekolah Dasar (SD) lebih menyukai olahraga permainan dari pada olahraga atletik. Banyak hal yang menyebabkan kurangnya minat anak-anak terhadap olahraga atletik, diantaranya kurang menariknya penyajian cabang olahraga ini oleh para pendidik atau pengajar di sekolah yang menyampaikan materi tentang kemampuan atletik, masih kurangnya penguasaan keterampilan dasar serta kondisi fisik yang dimiliki oleh atlet khususnya kemampuan lari sprint atau lari cepat, lemahnya gerak seorang anak di usia sekolah, banyak siswa yang memiliki berat badan yang berlebih, dan banyak pula yang tidak dapat melakukan lari dengan sempurna sehingga hasil yang dicapai tidak maksimal, minimya fasilitas olahraga di sekolah juga mempunyai pengaruh yang besar terhadap olehraga atletik.

Menurut Adisasmita (1992:35), "Sprint atau lari cepat adalah semua nomor lari yang dilakukan dengan kecepatan penuh atau kecepatan maksimal sepanjang jarak yang harus ditempuh". Dalam lari jarak pendek kemampuan biomotor yang paling dominan dan sangat penting adalah kecepatan.

Kecepatan lari pada nomor sprint ditentukan oleh panjang langkah dan frekuensi langkah sebagaimana dikemukakan oleh Jonath (1986:58) bahwa "Kecepatan lari adalah hasil kali antara panjang dan frekuensi (jumlah per detik) langkahnya, siapa yang ingin berlari cepat harus membuat langkah lebih panjang dan membuat langkah lebih banyak tiap detiknya".

Panjang tungkai dan berat badan merupakan faktor yang sangat membantu seorang pelari untuk mendapatkan kecepatan maksimal sehingga hasil lari yang dilakukan akan sempurna. Dari latar belakang diatas maka peneliti tertarik unttuk meneliti hubungan panjang tungkai dan berat badan terhadap kemampuan lari sprint 60 meter. Untuk itu peneliti mengangkat sebuah judul, “ Hubungan panjang tungkai dan berat badan terhadap kecepatan lari sprint 60 meter. 
Sesuai latar belakang masalah, maka munculah permasalahan yang dirumuskan dalam bentuk pernyataan sebagai berikut :

1) Apakah ada hubungan panjang tungkai dengan kecepatan lari 60 meter pada siswa putra kelas $\mathrm{V}$ SDN Beji 03 Tulis?

2) Apakah ada hubungan berat badan dengan kecepatan lari 60 meter pada siswa putra kelas $\mathrm{V}$ SDN Beji 03 Tulis?

3) Apakah ada hubungan antara panjang tungkai dan berat badan secara bersama-sama dengan kecepatan lari 60 meter pada siswa putra kelas V SDN Beji 03 Tulis?

\section{METODE PENELITIAN}

Penelitian ini merupakan penelitian korelasional yaitu suatu penelitian yang dilakukan untuk mengetahui tingkat hubungan antara dua variabel atau lebih tanpa melakukan perubahan, tambahan atau manipulasi terhadap data yang sudah ada (Arikunto, 2010: 4). Jenis penelitian ini merupakan penelitian kuantitatif. Penelitian ini bertujuan untuk mengkaji adakah hubungan berat badan dan panjang tungkai terhadap lari sprint $60 \mathrm{M}$.

Penelitian ini adalah jenis penelitian yang bersifat deskriptif yang bertujuan untuk mengetahui ada tidaknya hubungan antara panjang tungkai dan berat terhadap lari sprint 60 meter siswa putra kelas V SDN Beji 03 Tulis.

Dengan demikian model desain penelitian yang digunakan secara sederhana dapat dilihat pada gambar berikut ini:

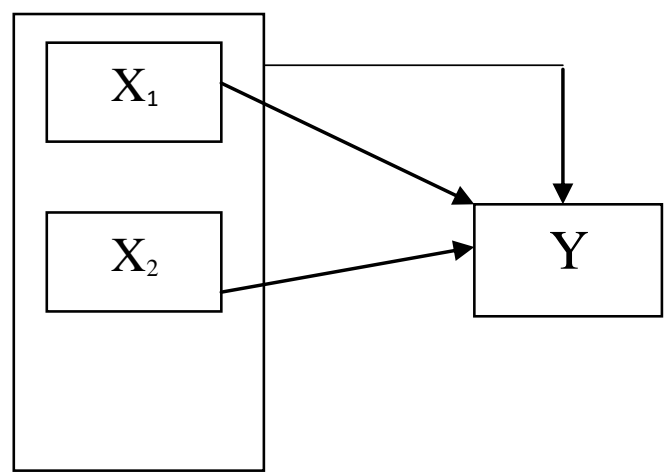

Gambar Desain penelitian korelasional Sumber : S. Margono, 2010: 139

Keterangan:

$\mathrm{X}_{1}$ : Berat badan

$\mathrm{X}_{2}$ : Panjang tungkai

Y : Kemampuan lari 60 meter

Adapun yang dijadikan populasi peneliti adalah semua siswa putra kelas V SDN Beji 03 Kecamatan Tulis, Kabupaten Batang. Sampel yang digunakan adalah semua jumlah 
populasi. Jumlah sampel adalah 30 siswa.

Teknik nalisis data meliputi uji normalitas pada distribusi data penelitian ini menggunakan rumus Kolmogorof-Smirnov, perhitungan uji data normalitas dengan menggunakan SPSS. Analisis korelasi sederhana adalah untuk mengukur keeratan hubungan secara linier antara dua variabel yang mempunyai distribusi data normal dan nalisis korelasi ganda Analisis korelasi ganda adalah untuk mencari besarnya hubungan dan kronstribusi dua variable bebas (x) atau lebih secara simultan ( bersama-sama) dengan variable terikat $\mathrm{Y}$.

\section{HASIL DAN PEMBAHASAN}

\section{Hasil Penelitian}

Data yang digunakan untuk melakukan analisis data penelitian adalah hasil pengukuran panjang tungkai, hasil pengukuran berat badan dan hasil kecepatan lari sprint 60 meter pada siswa putra SDN Beji 03 kecamatan Tulis kabupaten Batang tahun 2018.

Hasil pengukuran berat badan siswa yang diperoleh terberat $55 \mathrm{~kg}$ dan paling rendah $23 \mathrm{~kg}$. Adapun distribusi frekuensi data berat badan siswa putra kelas V sebagai berikut :

Tabel Distribudi Berat Badan Siswa Putra Kelas V.

\begin{tabular}{|c|c|c|c|}
\hline NO & $\begin{array}{c}\text { KELOMPOK } \\
\text { NILAI }\end{array}$ & FREKUENSI & F \% \\
\hline 1 & $53-55$ & 1 & 3,333 \\
\hline 2 & $50-52$ & 1 & 3,333 \\
\hline 3 & $47-49$ & 1 & 3,333 \\
\hline 4 & $44-46$ & 1 & 3,333 \\
\hline 5 & $41-43$ & 2 & 6,667 \\
\hline 6 & $38-40$ & 6 & 20,000 \\
\hline 7 & $35-37$ & 4 & 13,333 \\
\hline 8 & $32-34$ & 7 & 23,333 \\
\hline 9 & $29-31$ & 2 & 6,667 \\
\hline 10 & $26-28$ & 3 & 10,000 \\
\hline 11 & $23-25$ & 2 & 6,667 \\
\hline & JUMLAH & 30 & 100 \\
\hline
\end{tabular}

Hasil pengukuran panjang tungkai siswa diperoleh paling panjang $89 \mathrm{~cm}$ dan terpendek $60 \mathrm{~cm}$. Adapun distribusi frekuensi data panjang tungkai siswa putra kelas V sebagai berikut : 
Tabel Distribusi Panjang Tungkai Siswa Putra Kelas V

\begin{tabular}{|c|c|c|c|}
\hline NO & $\begin{array}{c}\text { KELOMPOK } \\
\text { NILAI }\end{array}$ & FREKUENSI & F\% \\
\hline 1 & $87-89$ & 1 & 3,33 \\
\hline 2 & $84-86$ & 1 & 3,33 \\
\hline 3 & $81-83$ & 1 & 3,33 \\
\hline 4 & $78-80$ & 3 & 10,00 \\
\hline 5 & $75-77$ & 9 & 30,00 \\
\hline 6 & $72-74$ & 2 & 6,67 \\
\hline 7 & $69-71$ & 6 & 20,00 \\
\hline 8 & $66-68$ & 4 & 13,33 \\
\hline 9 & $63-65$ & 1 & 3,33 \\
\hline 10 & $60-62$ & 2 & 6,67 \\
\hline & & & 100 \\
\hline
\end{tabular}

Waktu yang diperoleh tercepat 9,48 detik dan paling lambat 12,74 detik. Adapun distribusi frekuensi lari sprint 60 meter siswa putra sebagai berikut:
Tabel Distribusi Frekuensi Lari Sprint $60 \mathrm{M}$

\begin{tabular}{|c|c|c|c|}
\hline NO & $\begin{array}{c}\text { KELOMPOK } \\
\text { NILAI }\end{array}$ & FREKUENSI & F\% \\
\hline 1 & $9,01-9,5$ & 1 & 3,33 \\
\hline 2 & $9,51-10$ & 7 & 23,33 \\
\hline 3 & $10,01-10,5$ & 7 & 23,33 \\
\hline 4 & $10,51-11$ & 3 & 10,00 \\
\hline 5 & $11,01-11,5$ & 5 & 16,67 \\
\hline 6 & $11,51-12$ & 1 & 3,33 \\
\hline 7 & $12,01-12,5$ & 3 & 10,00 \\
\hline 8 & $12,51-13$ & 3 & 10,00 \\
\hline \multicolumn{2}{|c|}{ JUMLAH } & 30 & 100 \\
\hline
\end{tabular}

Uji normalitas menggunakan SPSS dengan tabel Kolmogorov-Smirnov output program SPSS yang dihasilkan pada ketiga variabel di atas seperti Tabel berikut. 
Tabel Output SPSS Uji Normalitas

\begin{tabular}{|l|c|c|c|c|c|c|}
\hline \multirow{2}{*}{ Tests of Normality } & \multicolumn{7}{|c|}{ Kolmogorov-Smirnov ${ }^{\mathrm{a}}$} & \multicolumn{3}{c|}{ Shapiro-Wilk } \\
\cline { 2 - 7 } & Statistic & df & Sig. & Statistic & df & Sig. \\
\hline Berat_Badan &, 121 & 30 &, $200^{*}$ &, 960 & 30 &, 304 \\
\hline Pjg_Tungkai &, 115 & 30 &, $200^{*}$ &, 977 & 30 &, 751 \\
\hline Lari_60 &, 143 & 30 &, 122 &, 914 & 30 &, 018 \\
\hline *. This is a lower bound of the true significance. & & & & \\
\hline
\end{tabular}

Berdasar tabel diperoleh pada data berat badan diperoleh sig $=0,200>0,05$ $(\alpha=5 \%=0,05), \mathrm{H}_{0}$ diterima berarti data berat badan berdistribusi normal, sedangkan pada data panjang tungkai diperoleh sig $=0,200>0,05 \quad(\alpha=$ $5 \%=0,05$ ) berarti data panjang tungkai juga berdistribusi normal. Sedang untuk data panjang lintasan lari sprint $60 \mathrm{~m}$ diperoleh $\mathrm{sig}=0,122>0,05$ $(\alpha=5 \%=0,05)$ berarti data panjang tungkai juga berdistribusi normal .

\section{Diskusi Hasil Penelitian}

Hasil penelitian diperoleh Uji

korelasi berat badan terhadap kemampuan lari 60 meter $\left(\mathrm{X}_{1}-\mathrm{Y}\right)$ dengan menggunakan SPSS hasil Correlations output program SPSS yang dihasilkan adalah diperoleh sig $=0,000<$ $0,05(\alpha=5 \%=0,05), \mathrm{H}_{0}$ ditolak berarti Terdapat hubungan yang positif dan signifikan antara berat badan dan kemampuan lari $60 \mathrm{~m}$. Darai tabel nilai sebesar $\mathrm{r}=0,716$ menunjukan hubungan yang tingi sebesar 71,6 \% artinya semakin ringan badan siswa maka kemampuan lari semakin cepat.

Uji korelasi panjang tungkai terhadapkemampuan lari 60 meter $\left(\mathrm{X}_{2}-\right.$ $\mathbf{Y})$ diperoleh $\operatorname{sig}=0,002<0,05(\alpha=$ $5 \%=0,05) \mathrm{H}_{0}$ ditolak berarti terdapat hubungan yang positip dan signifikan antara panjang tungkaidan kemampuan lari $60 \mathrm{~m}$. Darai tabel nilai sebesar $\mathrm{r}=$ 0,516 menunjukan hubungan yang sedang sebesar $51,6 \%$ artinya semakin panjang tungkai siswa maka kemampuan lari semakin cepat. 
Uji korelasi panjang tungkai, berat badan terhadap kemampuan lari 60 meter $\left(\mathrm{X}_{1}, \mathrm{X}_{2}-\mathrm{Y}\right)$ Uji korelasi ganda menggunakan SPSS dengan Correlations output program SPSS yang dihasilkan diperoleh sig $=0,000<0,05(\alpha=5 \%=$ 0,05 ) ), $\mathrm{H}_{0} \mathrm{di}$ tolakberarti panjang tungkaidan berat badan berhubungan secara simultan dan signifikan terhadapkemampuan lari $60 \quad \mathrm{~m}$. Berdasarkan tabel Model Summary bahwa hubungan antara panjang tungkaidan berat badan (secara simultan/bersama-sama) terhadap kemampuan lari $60 \mathrm{~m}$ adalahh 0,719 ini menunjukan hubungan yang tinggi.Sedangkan kontribusi atau sumbangan secara simultan variabel panjang tungkai dan variabel berat badan terhadap kemampuan lari $60 \mathrm{~cm}$ adalah $51,6 \%$ sedangkan $\quad 48,1 \%$ ditentukan oleh variabel lainya.

\section{SIMPULAN}

Dari hasil penelitian,analisis data dan pembahasan diperoleh simpulan sebagai berikut :

1) Ada hubungan korelasi panjang tungkai dengan kecepatan lari sprint 60 meter menghasilkan koefisien korelasi sebesar 0,516.
2) Ada hubungan berat badan dengan kecepatan lari sprint 60 meter karena korelasi berat badan dengan kecepatan lari sprint 60 meter menghasilkan koefisien korelasi sebesar 0,716 .

3) Ada hubungan yang signifikan antara panjang tungkai, berat badan, dengan kecepatan lari sprint 60 meter taraf signifikan, karena korelasi panjang tungkai, berat badan dengan kecepatan lari sprint 60 meter menghasilkan koeffisien korelasi sebesar 0,719 .

\section{DAFTAR PUSTAKA}

Adisasmita, Yusuf. 1992. Olah Raga Pilihan Atletik. Jakarta: Depdikbud

Aminudin. 2010. Atletik dan Tekniknya. Jakarta : Quadra

Bahagia, Yoyo. 1999. Atletik. Jakarta: Depdikbud

Dikdik Z.S. 2017. Mengajar dan Melatih Atletik. Bandung : Remaja Rosda Karya

Kaisar, A. A. (2016). Hubungan Antara Berat Badan, Panjang Tungkai Dan Daya Ledak Otot Tungkai Dengan Kemampuan Lari Sprint 60 Meter Siswa SDN Tanggul Patompo I Makassar.

Komarudin. 2016. Penilaian Hasil Belajar Pendidikan Jasmani dan Olah Raga. Bandung : Remaja Rosda Karya 
Munasifah. 2008. Atletik Cabang Lari.

Semarang : Aneka Ilmu

Pradana, A., \& Aji, A. K. H. M. A. D.

(2018). Kontribusi Tinggi

Badan, Berat Badan, Dan

Panjang Tungkai Terhadap

Kecepatan Lari Cepat (Sprint)

100 Meter Putra (Studi pada

Mahasiswa Pendkesrek

Angkatan $2010 \quad$ Universitas

Negeri Surabaya). Jurnal

Kesehatan Olahraga, 2(2)

Samsudin, M., Indonesia, U. N. P. G.

R., \& Kediri, U. Hubungan

Antara Power Tungkai Dan

Panjang Tungkai Dengan

Kemampuan Lari Sprint 100

Meter Pada Siswa Kelas Vii Smp

Negeri 3 Ngadirojo Tahun

Pelajaran 2015/2016

Mundisari, R.,Hubungan Antara

Panjang Tungkai, Berat Badan,

Dan Daya Ledak Otot Tungkai

Terhadap Kecepatan Lari Sprint

60 Meter Pada Siswa Putri

Kelas VII SMP N 2 Gondang

Nganjuk Tahun Ajaran

2015/2016, Skripsi,

Penjaskesrek, FKIP UN PGRI

Kediri, 2016

Kaisar, AzarAbuzair., (2016) Hubungan antara berat badan, panjang tungkai dan daya ledak otot tungkai dengan kemampuan lari sprint 60 meter siswa SDN Tanggul Patompo

Makassar. S1 thesis, FIK.

Teguh T. 2016. Buku Pintar Olah Raga.

Yogyakarta. Perpuatakaan Baru 